\title{
Poliitilised rituaalid ja diskursused Kärnteni liidumaa näitel
}

\begin{abstract}
Jurij Fikfak
Teesid: Artiklis käsitletakse kahte rituaalset tava Klagenfurtis (slov Celovec), Austria kõige lõunapoolsema liidumaa Kärnteni pealinnas. Esimene neist on seotud 10. oktoobriga, mil Klagenfurtis tähistatakse 1920. aasta rahvahääletuse aastapäeva. Toona hääletas enamik inimesi selle poolt, et Kärnten jääks Austria - Austria-Ungari kaksikmonarhia järeltulija - koosseisu. Teine rituaal - mälestuskõnd (sks Gedenkgehen, slov Spominska hoja) - on tunduvalt hilisem. Analüüsitakse erinevaid kultuurilisi tavasid, samuti sümbolite ja ruumi kasutamist ning meedia-, riiklikku ja rahvuslikku diskursust.
\end{abstract}

Märksõnad: alternatiivsed kombed, diskursuste kasutamine, mälestuskõnd, natsism, rahvahääletus, rituaalid

Poliitilised rituaalid on kombed, mis joonistuvad välja konkreetsetes kronotoopides. Nad väljendavad ja materialiseerivad kuuluvustunnet, identiteetide kujunemist ning kohalike, regionaalsete, etniliste, rahvuslike ja riiklike olemite kehtestamist. Samuti esindavad nad sotsiaalset kohesiooni, enesemääratlust, sotsiaalset kuuluvust ning teise välistamist. Poliitilised rituaalid on vältimatud sotsiaalses integratsioonis (Lukes 1975), hierarhiates, inimsuhetes ja võimu kasutamises. Neid kasutatakse korduvalt, aasta-aastalt, et määratleda, kehastada ja materialiseerida etnilisi, keelelisi ja teisi barjääre, mis ei lase kogukonnas sotsialiseerunud üksikisikul jääda mõjutamatuks või kõhklevaks. Nagu Steven Lukes (1975) on märkinud, mobiliseerivad poliitilised rituaalid eelarvamusi, kuid tõstatavad ka küsimusi erinevate diskursuste omavahelistest seostest, nagu näiteks valitsusparteide ametlik poliitiline diskursus, meediadiskursused, nn kaine mõistuse diskursus ja subkultuuri diskursus, mis esineb peamiselt erinevates ekstremistlikes rühmitustes. Rituaalid kõnetavad ühiskonda ja selle institutsioone, samuti räägivad neist kõigist ning võimaldavad ja taasloovad nende välistavaid või kaasavaid omadusi (North 1991).

Kognitiivse eelarvamuse dünaamikat võis jälgida Trieste piirkonnas 10. veebruaril 2007. aastal toimunud mälestuspäeval (Il Giorno del ricordo) (vrd Fikfak 
2009), mil avalikkuse ette toodi poliitiliste vaadete pingeline vastastikune mõju: Itaalia presidendi kommentaarid verejanuliste slaavlaste aadressil, Trieste piirkonnas valitsevad poliitilised ja meediadiskursused ning lõpuks ka Movimento Sociale Fiamma Tricolore ehk MS FT (Sotsiaalne Liikumine Trikoloori Leek) rühmitise subkultuurilised diskursused. MS FT demonstreeris oma vaateid, pihustades neonatsliku ja neofašistliku sisuga grafitit monumentidele, mis olid pühendatud Teises maailmasõjas hukkunud partisanidele Trebčest (Trebiciano) ja Padričest (Padriciano) kuni Boljunecini (Bagnoli della Rosandra) (Fikfak 2009). Rühmitise side neonatsliku diskursusega tõusis uuesti esile 25. aprillil, Itaalia rahvuspühal, Bazovica (Basovizza) karstilehtri juures asuva monumendi juures, mis on pühendatud itaallaste ja teiste rahvuste väljarändamisele Dalmaatsiast ja Istriast, ning itaallastele ja kommunistliku süsteemi vastastele, kes tapeti sõja lõppjärgus või natuke pärast seda, kusjuures sajad neist visati karstilehtrisse.

Poliitilised rituaalid võimaldavad poliitikutel teadlikult valida rituaalseid kohti, sündmusi ja sobilikke tõlgendusi, ning lubavad ametlikul poliitikal ära kasutada või piirata subkultuuriliste diskursuste ja tegevustega seotud argumente. Trieste piirkonna linnapead ja linnavalitsuste esindajad, nii itaallased kui sloveenid, kogunevad iga aasta 1 . novembril, austamaks langenuid mõlemal poolel. Näiteks Bazovicas kogunevad nad nii karstilehtriohvrite mälestuskohale kui ka kohta, kus 1930. aastal hukati neli antifašistliku organisatsiooni TIGR liiget (Fikfak 2009). Riik kehtestab ja säilitab korda oma esindajate vahendusel; selle käigus edastatakse põhiväärtused ja suunised, millel on potentsiaali muuta teisi diskursusi, kaasa arvatud triviaalsed, terve mõistusega seotud ja subkultuurilised diskursused (Hayek 1960).

Sellised muutused ja otsused, st teadlik poliitiliste ja valitsevate diskursuste kujundamine, mis on mõeldud takistama tuleviku vastuolusid ning lähendama kunagi lahkarvamustes olnud ja vaenulikke rahvusi ning riike (eriti Prantsusmaad ja Saksamaad, kuid ka teisi rahvusi ja riike), olid aluseks ka Euroopa ühendamise ideele, mille sõnastasid Jean Monnet ja Robert Schuman. ${ }^{1}$ Selle idee vaieldamatuks osaks oli katse mõjutada avalikku arvamust ametliku diskursuse kaudu ning seejärel kasutada sedasama avalikku arvamust, mõjutamaks subkultuurilisi diskursusi, kuna just need tekitavad sageli rahulolematust, vastasseisu ja erinevate gruppide vastuolusid.

Näiteid neist dünaamilistest suhetest erinevate valitsevate, meedia-, triviaalsete ja subkultuuriliste diskursuste vahel ning nii mälu kui ka identiteedi erinevate praktikate ja nende ilmnemise vahel võib leida ka Kärntenis, kõige lõunapoolsemal Austria liidumaal.

Pärast seda, kui Austria-Ungari impeerium 1920. aastal mitmeks riigiks lagunes, sai Austria piiriküsimustest peamine tüliõun vaidlustes Itaalia ning 
Serblaste, Horvaatide ja Sloveenide Kuningriigiga (SHS). Itaallased nõudsid ja saidki endale Tirooli lõunaosa ja Tarvisio ümbruse oru. 10. oktoobril 1920. aastal viidi Kärntenis läbi rahvahääletus, mille käigus paluti elanikel otsustada, kas nad soovivad ühineda Austria või Serblaste, Horvaatide ja Sloveenide Kuningriigiga. Enamik nii saksa- kui sloveenikeelsetest hääletajatest otsustasid Österreich - Avstrija rohelise valimissedeli kasuks, valides seega oma kodumaaks Austria-Ungari monarhia järeltulija. Sloveenid valisid Austria peamiselt majanduslikel kaalutlustel (vrd Moritsch 2002), kuna kogu piirkond tundis loomulikku tugevat sidet Klagenfurtiga. Nende otsust mõjutasid tugevalt ka Austria võimude lubadused kaitsta sloveenide kultuurilisi ja keelelisi õigusi selles piirkonnas. Teine faktor, mida tuleks arvestada, on windischi ehk Zwischenmenschen'i kategooria, mille võttis kasutusele Martin Wutte (vrd Zinkner 2009; Valentin 2006) ja mis kõnetas edukalt hääletajaid saksameelsetes sloveeni peredes.

Järgmisel, 1921. aastal, tähistati rituaalse mälestusüritusega rahvahääletuse tulemust, tänu millele jäi Kärnten 'vabaks ja jagamatuks'. Nagu kirjutas Kärnteni praegune kuberner ja Austria Sotsiaaldemokraatliku Partei liige dr Peter Kaiser oma ametlikus teadaandes, oli isegi see kõige esimene mälestusteenistus selgelt saksameelne ja seega mitte ainult Serbia ja Jugoslaavia, vaid ka Sloveenia-vastane.

Nii Kärnteni kalender, uudised kui ka kirjandus (Burz \& Pohl 2005) viitavad sellele, et rahvahääletuse ritualiseeritud mälestamine on sündmus, millel on vähe tegemist tavapärase rituaalse kalendriga (nagu nt lihavõtted, uusaasta, vastlad). Igal aastal tähistatakse seda sündmust koolides. Sel päeval ei ole tunde, ka ametiasutused on suletud. Riigijuhid teevad meediakanalites ametlikke avaldusi, asetavad pärgi monumentide juurde, mis on pühendatud brambovci'le, relvastatud kaardiväelasele, kes võitles selle eest, et Kärnten jääks Austria koosseisu; samuti toimub Kärnteni Maapäeva mälestusistung. Nimetatud mälestusüritused on üldjuhul palju pidulikumad kui need, mis on pühendatud rahvuspühale 26. oktoobril, mis tähistab päeva 1955. aastal, mil Austria parlament kirjutas Viinis alla neutraalsuse deklaratsioonile. Viimastel kümnenditel on suuremaid pidustusi korraldatud peamiselt iga viie või kümne aasta järel. Rituaali ratsionaalsus ja ökonoomsus on silmnähtav: rahvarikkaid rongkäike organiseeriti Kärnteni pealinnas Klagenfurtis 1995. aastal, tähistamaks rahvahääletuse 75 . aastapäeva, 2000. aastal 80. aastapäeva auks, ja 2010. aastal 90. aastapäeva tähistamiseks. Järgmine suurem mälestusüritus on kavandatud aastaks 2020, märkimaks saja aasta möödumist rahvahääletusest.

1995. aasta mälestusrongkäigust võttis hinnanguliselt osa umbes 20000 inimest ning 100000 inimest tuli seda vaatama. Kuid aastal 2010, mil ma jäädvustasin hetki pidulikust paraadist (Festumzug), oli rongkäigus ainult 
16000 kuni 17000 aktiivset osavõtjat, kusjuures pealtvaatajate arv pole teada. Uudistes mainiti pealtvaatajate arvuks alates 5000 kuni üle 10 000; enamik neist olid kogunenud Novi trg'i (sks Neuer Platz), mis on Klagenfurti peaväljak. Väljakule püstitati spetsiaalne tribüün ja rongkäigus osalejad möödusid marssides riigi aukülalistest ja kirikuvõimu esindajatest, kelle hulgas olid Austria president Heinz Fischer, kantsler Werner Faymann, riigikuberner Gerhard Dörfler, Gurk-Klagenfurti piiskop Alois Schwarz ja paljud teised. Sloveenia võimude esindajaid kohal ei olnud. Nagu fotodelt võib tuvastada, osales sündmuses üksainus Kärntenis aktiivselt tegutsevate sloveenide partei ametlik esindaja, dr Marjan Sturm, ${ }^{2}$ sest ühegi teise partei esindajad ei olnud kutsutud.

Jälgides seda rongkäiku kohapeal, televisiooni vahendusel või YouTube'i videos ja vaadates ära kogu DVD video, mis on üle seitsme tunni pikk, saame suhteliselt kompaktse pildi sündmusest, mida ilmestavad Kärnteni liidumaa lippude ja mõnede Austria lippude värvid. Veel üks iseloomulik värv on Kärnteni rahvariiete silmatorkav pruun. Kõned, mis peetakse saksa keeles, keskenduvad selle ajaloolise otsuse ülistamisele, mis kindlustas Kärnteni ühtsuse ja jjagamatuse' vana ja uue Austria Vabariigi piirides, mis on endise Austria-Ungari impeeriumi peamised järglased. Näeme sõidukeid suurte reklaamtahvlitega, mis kujutavad ajaloolisi sündmusi koomiksiga sarnanevas vormis ning kasutavad või imiteerivad kunstilisi lahendusi, mis olid iseloomulikud 1920. aasta propagandamaterjalidele. Nad kujutavad ajaloolist lühiülevaadet alates otsustavatest sündmustest, mis leidsid aset pärast sõda, 1918. ja 1920. aasta vahel ja lõpetades Saksamaa triumfiga rahvahääletusel oktoobris 1920.

Kohapealt saadud muljed Klagenfurtist, aga samuti videomaterjalist, ajalehtedes ilmunust ja internetifoorumitest annavad tunnistust sellest, et see sündmus on riigi kuvandi vaieldamatu koostisosa. Ideaaltüüpiliselt taaselustab iga 1920. aasta rahvahääletuse mälestusüritus Kärnteni olemust ja maa ühtsust üha uuesti. Rongkäigu jälgimisel otsustasin alustada selle algusest ja liikuda lõpu suunas. Panin tähele, et rongkäigust osavõtjate arv ületas oluliselt tee ääres seisvate pealtvaatajate arvu. Viimaseid oli kõige arvukamalt rongkäigu lõpus, Novi trg'il, ja poodiumidel, mis olid reserveeritud kutsutud külalistele. Ajalehtedes (Kleine Zeitung, Kärntner Zeitung jt) avaldatud informatsiooni kohaselt võttis pidustustest osa umbes $20000-25000$ inimest, mis on vähem kui leinajate arv dr Jörg Haideri, Kärnteni kuberneri auks peetud mälestusteenistusel (osales rohkem kui 30000 inimest). Aktiivsete osalejate ja pealtvaatajate arvuline suhe räägib sellest, et paraadi korraldatakse enda näitamiseks ja et see on rituaal, milles nii osavõtjad kui ka pealtvaatajad, kellest paljud kannavad traditsioonilist kohalikku pruuni kostüümi või kitsa vöökohaga maani kleiti, saavad kinnitust oma minapildile. Veelgi enam, ava- 
likus ruumis ja peamiselt Austria pealtvaatajate ning riigipeade ja kirikutegelaste ees muutuvad rongkäigus osalejad Kärnteni kehastuseks. Sündmusest võtab osa 5-6 protsenti Kärnteni rahvastikust. Nende roll Kärnteni pealinna Klagenfurti tänavatel liikuvas rongkäigus - ja ainuüksi nende kohalolek määratleb Kärnteni kronotoopi, kinnitab soovitud maailmavaadet ja uuendab seeläbi Kärnteni identiteeti.

Me peame silmas pidama seda, kes presenteerib end neis olulistes pühades paikades Kärnteni pealinnas ja kuidas nad seda teevad; mil määral on riiklik (Austria), etniline (saksa või sloveeni) ja regionaalne identiteet kaasatud sellisesse rituaalsesse käitumisse ja tegevustesse ning mil määral nad vajavad ja loovad erinevat teist, kehtestamaks 'kärntenlust'. Mil määral nad vajavad või kasutavad kas põlist etnilist rahvastikku, st sloveene, või immigrante, nt tšetšeene?

Kui me hindame olukorda Kärntenis, võttes arvesse kakskeelseid tänavasilte, koolide õppekavasid, riigikeelt, jne - saksa enamuse ja sloveeni vähemuse vahekorra põhilisi näitajaid - muutub oluliseks küsimus üldiste ja käesoleval juhul ka rituaalsete diskursuste erinevast struktureerimisest saksa ja sloveeni poolel. Kuidas ja kus saaksid ja võiksid inimesed omaks võtta Kärnteni-Saksa enesepresentatsiooni, mis tajub ja loob uuesti oma ajalugu kõige lõunapoolsema Saksa piirina ja kaitsekantsina omaenda, saksa kultuuri, ja võoramaiste slaavlaste kultuuri vahel? Või sloveenide realistlikku ja mütoloogilist enesemõistmist, mis hõlmab Kärnteni kui sloveenide ajaloolise keskuse ja kõige põhjapoolsema sloveenluse piiri kuvandeid?

Nii või teisiti on selle piduliku sündmuse edastatud ja uuendatud kuvandid ja sõnumid ning selle paraadi (Festzug) rituaalsus muutunud inimeste silmis reaalsuseks - sõnad on muutunud tegevusteks (Austin 1962). Mineviku sündmused, mälestused ja vaimsuse märgid on materialiseerunud (Oevermann 2001), esitletuna kõige tähtsamate rahvuslike, piirkondlike ja kirikuvõimude esindajate ees. Samuti on nad internetifoorumites ja igapäevaelus toimuvate arutelude osaks. Nad mõjutavad otsuseid nii selle kohta, milliseid mälestusi tuleks omaks võtta koolides, kogukonnas või näiteks muuseumides, kui ka selle kohta, kuidas seda peaks saavutama. Ruumid, milles rituaalsed ettevõtmised aset leiavad, on metonüümsete metafooride ruumid, mis sümboliseerivad ühtsust, mida toetavad puna-kollased lipud. Sünesteetiliselt, muusika ja järjekindla, peaaegu militaristliku enesepresentatsiooni saatel, tähistavad ja uuendavad need ruumid otsustavust jääda saksameelseks. 


\section{Muutuste tuules}

Eelmainitu on ainult esialgne, kuid siiski valitsev vaatenurk. Aasta 1995 tõi standardkuvandisse esimesed tsensuurijuhtumid, mis kaasnesid sloveenikeelse kõnega riigiassambleel. Aasta 2010 tähistas järjekordset nihet enesepresentatsiooni stsenaariumis: mälestusrongkäiguga ühinesid ka kohalike kogukondade esindajad, kes kandsid kakskeelseid loosungeid sloveeni ja saksa keeles. Nende muutuste põhjusi võib kahtlemata leida nii poliitiliste diskursuste kui ka Kärnteni peamiste jõudude tasandil, mis muutusid pärast riigikuberner dr Jörg Haideri ootamatut surma. Teine muutuste põhjus peitub rituaalsete praktikate olemuses ja poliitiliste diskursuste realiseerumises, mille üle pidevalt vaieldakse ja mis on pidevalt kriisiolukorras. Siinkohal võiks viidata Charles Sanders Pierce'i kriisifilosoofiale Ulrich Oevermanni (2001) tõlgenduses, mis vaatleb kriisi ja rutiini kui inimese elu kaht iseloomulikku osa. Oma järjestikkuse iseloomu tõttu on rutiinseks muutunud ja ritualiseeritud praktikad pideva kontrolli all ja pidevate läbirääkimiste objektiks. Ühelt poolt on vaja välja selgitada, kes kujundab diskursusi ja kes taasloob kombestikku. Teisalt peame tuvastama üldiste diskursuste struktureeringud selles sündmuses ning nišid või nihked, mis olid ja on praegugi iseloomulikud ja tähtsad osavõtjate jaoks, kuid samas nähtamatud pealtvaatajatele ja laiemale üldsusele. Milline on suhe erinevate diskursuste vahel ja kuidas need avalikkuses vastukaja leiavad?

Küsimus on siin selles, kes võib end presenteerida, kes on oodatud osa võtma ja kelle osavõtt välistatakse. Kes võib eneseesitluse mängus osaleda ja aidata seega identiteeti kujundada? Täpsemalt, millisel tasandil on see küsimus nii enese kui ka teise välistamisest, või siis nii enese kui ka teise kaasahaaramisest? Kuidas ja mil määral on need välistamised ja kaasahaaramised ebaõnnestunud kohanemisprotseduuride lahutamatuks koostisosaks? Problemaatiline võib olla nii rituaali läbiviimise koht kui ka rituaal ise. Kui me võtame aluseks Helge Gerndti (1979) osavõtjate määratluse ja seda laiendame, võime rääkida juhtidest, organisaatoritest, osavõtjatest, pealtvaatajatest, möödakäijatest, kaasahaaratutest ja nendest, kes on kas rituaali vastu või ignoreerivad seda.

Selles raamistikus eristub tugevalt Kärntenis toimuva sündmuse kuvand. Konservatiivsete parteide saksakeelsed liikmed, kes on Kärnteni patrioodid, osalevad mälestusüritustel, mida korraldavad maakaitsevägi (Abwehrkämpferbund) ja sellised poliitilised parteid nagu Jörg Haideri juhitu. Vastaspoole moodustavad sloveenid - nii nende järglased, kes hääletasid Jugoslaaviaga ühinemise poolt, kui ka nende, kes hääletasid Austria poolt ja hiljem mõistsid, et neile antud lubadused olid valed. Viimased üldjuhul ignoreerisid mälestusüritust ja eelistasid sel päeval tööd teha. 
2010. aasta sündmused aga näitasid, et see kuvand hakkab aegamööda muutuma; nii mõnedki sloveenid, kuigi mitte ürituse tulihingelised pooldajad, osalesid siiski Klagenfurti mälestusrongkäigus. Rühm inimesi Bistritsast laulis kõigi riigi ja kiriku esindajate ees isegi ühe sloveenikeelse laulu kohalikus murdes. Rongkäigu ja selle peamiste osavõtjate kuvand oli samuti erinev, sest Kärnteni saksameelne isamaaline kodanikuinitsiatiiv Heimatdienst ja selle juht, dr Josef Feldner ei olnud palutud üritust korraldama, isegi vaatamata sellele, et dr Josef Feldner oli sel ajal juba Konsensusgrupi liige, kuhu kuulusid ka dr Marjan Sturm, dr Stefan Karner, Heinz Stritzl ja Bernard Sadovnik. ${ }^{3}$

\section{Plakat: sarnane ja erinev}

Nagu juba mainitud, hääletas enamik kärntenlasi, kaasa arvatud suur osa sloveene, Austria poolt. Selliseks otsuseks oli erinevaid põhjusi: mõned neist puudutasid majandust, teised aga mitmesuguseid pingelisi olukordi. Praegu on küsimus selles, kuidas seda otsust selgitati ja esitati Klagenfurti pühalikul mälestusüritusel. Programm, mis trükiti plakatile, loetles pidustusi ja teisi sündmusi kronoloogilises järjekorras. Teatud mõttes kujutas see endast osavõtjate nimekirja, kellel oli õigus ja kohustus esindada kohalike elanike teatud kihte ja huvisid. Plakatilt võis leida kaks märkimis- ja arutlusväärset kirjet. Paremal pool oli tolleaegse Kärnteni kuberneri Gerhard Dörfleri pöördumine. Viimane oli Austria Tulevikualliansi (Bündnis Zukunft Österreich - BZÖ) juht, Klagenfurti lähedal autoõnnetuses hukkunud dr Jörg Haideri järeltulija. Oma pöördumises esitas tseremooniameister Döfler, nagu Harald Wydra (2009) teda nimetas, ametliku poliitilise tõlgenduse 90 aasta tagustele sündmustele.

Kärnten tähistab rahvahääletuse 90. aastapäeva moto all "Eile - Täna Homme”. Me peaksime koos rajama oma tuleviku meie ühise ajaloo vundamendile. 90 aastat tagasi tegid kärntenlased kindla otsuse jääda ühtseks ja jätkata elu Austria koosseisus. See pühendumus Kärnteni ühtsusele ei olnud lihtsalt demokraatia võit - see oli tol ajal valitseva natsionalismi otsustav kõrvaleheitmine, kuna saksa, sloveeni ja windischi keelt kõnelevad kärntenlased hääletasid koos uue Austria poolt ja SuurSerbia Kuningriigi vastu. ${ }^{4}$

See pöördumine puudutab peaaegu kõiki võtmeküsimusi, rahvahääletuse ümmargustel aastapäevadel organiseeritavat paraadi ja selle kuvandit. Pöördumine ise on seosetu, käsitledes nii omariiklust, rahvust kui etnilisust. Lisaks sisaldab see tekst ka üht elementi, mis rõhutab veelgi enam sloveenide ja kärntenlaste vahelist jagunemist: n-ö vahepealsete inimeste kohta kasuta- 
takse terminit 'windisch', millega tähistatakse neid, kes pole sakslased, kuid samas ka mitte enam sloveenid - need on inimesed, kes hakkavad muutuma sakslasteks. Nii pöördumises endas kui ka windischite eneseesitluses (windische.at) võib märgata kahte strateegiat. Esimest strateegiat surub peale dominantne konservatiivne diskursus, mida propageerib peamiselt Austria Vabaduspartei ja mille eesmärgiks on vähendada sloveeni keelekeskkonna ja kultuuri tähtsust Kärntenis. Seda strateegiat kasutatakse ka Kärnteni ja Sloveenia sloveeni kogukondade silmapaistvate esindajate esitatud nõudmiste ja lootuste välistamiseks. Teine strateegia on iseloomulik paljudele sloveeni kogukonna liikmetele, kelle vanemad ja vanavanemad rääkisid sloveeni dialekti, kuid ei käinud kunagi sloveenikeelses koolis ega osanud seetõttu selles keeles kirjutada. Kõige veenvama näite sellest samastumisest esitas Bertl Petrei, etnograaf ja etnoloog, kes kirjutas sellest oma autobiograafias pealkirjaga Kokolore (Petrei 1986), ning ka internetifoorumis windische.at (Petrei 1995). Petrei näeb windischit pigem kultuurilise kui etnilise enesemääratluse ja enesepresentatsioonina. See muuseumiringkondades tuntud intellektuaal mainib oma avalduses nii windischi kontseptsiooni laialdast levikut kuuluvust väljendava erilise vormina kui ka keelelist (eba)kompetentsust: ta kasutab terminit 'windisch', viitamaks inimestele, kes räägivad üht sloveeni keele dialekti, kuid ei ole suutelised seda kirjutama.

Üks plakati element äratab erilist tähelepanu: see viitab otsuse tegemise demokraatlikule iseloomule ja natsionalismivastasele võitlusele. Kasutades süntagmasid 'demokraatia võit' ja 'rahvusluse mittetunnustamine', tugineb riigikuberner tänapäeva diskursustele ja dihhotoomiatele. Kasutades aga süntagmat 'Suur-Serbia riik', loob ta teise kuvandi - kuvandi suuremast Serbiast, kultuurist, mis on vastuvõetamatu, ebademokraatlik, ning seotud natsionalismiga. See on kuvand, mida esindab serbia sõdur Kärnteni regionaalmuuseumi väljapanekus - see on sõdur, kes tahab alistada kogu Kärnteni ala. Riigikuberner kasutab tänapäeva diskursusi, loomaks ebakõla, mis võimaldab ignoreerida rahvuslust, mille tulemuseks oli Kärnteni tugev saksastamine 19. ja 20. sajandil.

Vihjeid kogukondade- ja keeltevahelistele suhetele Kärntenis võib märgata ka plakati vasakul poolel. ${ }^{5}$

\section{8. oktoober}

13.00 Kärnteni parlamendi istung parlamendihoone suures vapisaalis

15.00 Aastapäevale pühendatud tseremoonia parlamendihoone suures vapisaalis; kõned Austria presidendilt, föderaalkantslerilt ja riigikubernerilt, esinevad kaks noortekoori (Saksa ja Sloveenia); osaleb kogu sloveeni etniline kogukond (ORFi otseülekanne) 


\section{9. oktoober}

9.30 Rahvahääletuse mälestusüritus Annabichli sõjaväekalmistul asuva kenotaafi juures

11.00 Kärnteni 10. oktoobri rahvahääletuse tähistamine parlamendihoone õues, Kärnteni ühtsusmemoriaali ees

14.00 Pärgade asetamine kuberner Arthur Lemischi (Püha Kolmainsuse kirik Sankt Veit an der Glanis), Martin Wutte (Obermühlbach, Sankt Veit an der Glani lähedal), ja kolonelleitnant Ludwig Hülgerthi (Rottensteini härrastemaja) haudadele

Erilist huvi pakub mittesakslastest kärntenlaste esindatus, kes hääletasid Austria poolt ja tegid seega rahvahääletuse tähistamise 2010. aastal võimalikuks.

Mittesakslastest hääletajad olid esindatud ja programmi kaastatud kahel korral: esimene kord 2. oktoobril, üritusel, mille organiseerisid kirik ja Klagenfurti piiskop, ja teine kord 8. oktoobril, kaks päeva enne aastapäevaüritust, kui üksikisikud ja kutsutud külalised kogunesid vapisaali. Nad lisati nimekirja kui 'Einbindung der slow. Volksgruppe' (slov. etnilise kogukonna kaasamine). Enne kui analüüsida, kuidas sloveeni etniline kogukond programmi kaasati ja kes valiti seda esindama, peaksime andma hinnangu määratlusele, mis väljendus riigi ja riigikuberneri ametlikus enesepresentatsioonis ja mida mäletusürituse programm avalikkusele edastas. Kui ametlik plakat demonstreerib üsnagi selgeltnähtavat poliitilist praktikat ning kehtestab ja samaaegselt ka peegeldab dominantset poliitilist diskursust, siis mil määral on plakatil esindatud sloveeni etniline kogukond? Mida tähendab 'slov. etnilise kogukonna kaasamine'? Kas see tähendab, et poliitikud ei teadnud, kes täpselt seda kogukonda esindab ja kuidas nad seda teevad? Kas see tähendab, et kõneleja pidi määratama viimasel hetkel? Või et soovitud mõju saavutamiseks pidi kõneleja valima valitseva diskursuse pooldaja? Või oli kogukond nii lõhestunud, et sellel ei olnud tõelist, ühehäälselt valitud esindajat? Plakati analüüs ja võrdlus teiste osavõtjatega näitab, et kõik peale sloveeni etnilise kogukonna olid määranud kõnelejad ja valinud enesepresentatsiooni kindla vormi. Sloveeni etnilise kogukonna esindaja oleks saanud välja kuulutada ka ilma nime mainimata, sarnaselt sellega, kuidas kuulutati välja president, kantsler ja riigikuberner. Sõna 'slowenischen' asemel lühend 'slow.' fraasis 'Einbindung der slow. Volksgruppe' annab tulemuseks (ilmselt ettekavatsematu ja soovimatu) anonümiseeriva strateegia ja praktika, milles see, kes vastutab dominantse diskursuse eest, on samaaegselt ka sündmuse korraldaja. Käesoleval juhul korraldas sündmuse valitsus, kuberner, kes samaaegselt andis ka vähemusele õiguse end väljendada, ning piiras või vähendas sellesama vähemuse tunnustamist üksikasjalikult planee- 
ritud kronotoopi, mis määras kindlaks, kus ja kui kaua see vähemus võib end ametliku rituaalse praktika raamistikus presenteerida.

'Slov. etnilise kogukonna kaasamine' toimus dr Valentin Inzko osavõtul; viimane oli tol ajal Kärnteni Sloveenide Rahvusnõukogu esimees ning Bosnia ja Hertsegoviina eriesindaja Euroopa Liidus, lisaks sellele ka esimene inimene, kes viieteistkümne aasta jooksul oli Kärtneni parlamendihoone vapisaalis sloveeni keelt rääkinud. Tema isa oli sellessamas saalis kõnet pidanud 1995. aastal. Mis juhtus dr Inzko kõne ajal? Diplomaat dr Valentin Inzko, tolleaegne kõige silmapaistvam kõneleja Sloveenias, haaras võimalusest, mille talle oli andnud dr Marjan Sturm, kes lubas tal enda asemel rääkida, ja muutis planeeritud sloveeni kogukonna lühikese ja tähtsusetu enesepresentatsiooni - viie- kuni seitsmeminutilise kõne, mis pidi hõlmama viit kuni seitset protsenti mälestusürituse kestusest - 45minutiliseks kõneks. ${ }^{6}$ Ta esitas äärmiselt põhjaliku kokkuvõtte sloveenide ja sakslaste ajaloost Kärntenis. Selle põhisõnum oli, et just sloveeni kogukond aitas kaasa jagamatu ja ühtse Kärnteni olemasolule. Ta kirjeldas ka Kärntenit, kus mõlemad etnilised kogukonnad elaksid koos, austaksid teineteist ja pakuksid oma noortele turvalist tulevikku. Arutelud konservatiivsete Kärnteni haritlastega tõid päevavalgele asjaolu, et dr Inzko murdis kokkulepet ja kehtestamata reeglit sloveeni eneseesitluse kohta. Ta ületas kaugelt kõik kronotoobi piirid, mille dominantne diskursus oli sloveeni kogukonnale ette kirjutanud.

Kahe keele kasutamine plakatitel, kuulutustes ja teistes materjalides räägib ka suhetest rahvahääletuse mälestusüritusel. Olemasolevatel andmetel kasutati sloveeni keelt kahel korral: dr Inzko pöördumises aastal 2010 ja külade puhul, mis esitlesid end mõlemas keeles. Kõik teised materjalid, mida rahastas valitsus, nagu näiteks ametlik plakat, kuulutused, jne, avaldati saksa keeles.

Ametlikud kõned, mis peeti selle sündmuse raames mälestusparaadil, andsid samuti võimaluse kasutada sloveeni keelt. Kuid mitte ühtki sloveeni kõnelejat ei kaasatud - kõik kõned peeti saksa keeles. Ainuke inimene, kes julges Kärntenis teist keelt kasutada, oli Austria president dr Heinz Fischer, kes ütles kolm lauset saksa keeles, millele järgnes umbkaudne tõlge sloveeni keelde. See oli ametlik tervitus, pöördumine, mis vaatles seda üritust kontekstis, näidates, et Kärntenis eksisteerib kaks keelekogukonda. Tema pöördumise teine pool puudutas põhilist vaidlusküsimust tolleaegses Kärntenis - kakskeelseid silte. Ta lõpetas oma pöördumise, soovides kõigile head ja rahulikku tulevikku:

Werte Festgäste! Liebe Kärntnerinnen und Kärntner!

Cenjeni Častni Gosti! Drage Korošice in Korošci ! [---]

"Die Zeit ist reif". (Čas je zrel) habe ich schon im Juli in meiner Antrittsrede als wiedergewählter Bundespräsident gesagt. ${ }^{7}$ 
Ich wünsche dem Bundesland Kärnten und allen Menschen, die hier ihr Zuhause haben, eine gute und friedliche Zukunft.

Deželi Koroški želim dobro in mirno prihodnost.

[Austatud külalised! Kallid kärntenlased! [---]

"Aeg on küps," ütlesin ma juulis oma ametissepühitsemise kõnes, kui mind taas presidendiks valiti.

Ma soovin Kärnteni liidumaale ja kõigile inimestele, kes seda oma koduks peavad, head ja rahulikku tulevikku.

Ma soovin head ja rahulikku tulevikku kogu Kärntenile.]

Kõige olulisem lause, mida on ka kõige rohkem tsiteeritud nii pärast presidendivalimisi kui ka rahvahääletuse mälestusüritusel, oli ‘Aeg on küps'.

Ülalmainitud lausung avab ja väljendab kahte tasandit, millel etnilise grupi tegelikkust võib käsitleda rituaalses praktikas. Etnilist gruppi, vähemust (Minderheit) defineeritakse kui tähtsat probleemi või küsimust; see rõhutab mõlema keele kasutamist kohanimede siltidel, mis on vähemuse jaoks olulised. Samas lausung ‘Aeg on küps' ei viita vähemusküsimuse komplekssele lahendamisele; see kõnetab ainult üht osa, individuaalsust. Samal ajal toimib see lausung ka teisel, nimelt Austria riigi tasandil: presidendi väljendatud diskursuses on kakskeelsed sildid terviku, st Austria riigi lepingu lahenduseks. Vastavalt Austria-Viini ametlikule diskursusele täidaksid sildid kõige kriitilisemat ja, nagu Stefan Karner on öelnud, ebatäpselt defineeritud 7. punkti lepingus, mille alusel moodustati Austria riik. See oleks ka takistuseks sellistele olukordadele, nagu näiteks see, kui Rudi Vouk asetas vähemuse Kärnteni diskursuse keskmesse ja muutis topograafilised märgid keskseks, vähemusega seotud teemaks.

Kuna need olid ainsad ametlikud sloveenikeelsed sõnad, mida 10. oktoobril 2010. aastal räägiti, tegid nad selle kõne märkimisväärseks, osutades ühele kõige pakilisemale probleemile Kärntenis. Selles äärmiselt läbimõeldud ja, arvestades Kärntenis valitsevat situatsiooni, suhteliselt tasakaalustatud kõnes kujutab president ette, milline võiks olla 2020. aastal rahvahääletuse mälestusüritus, millega austerlased ja sloveenid tähistavad koos 100. aastapäeva. Samal ajal dr Fischer lihtsustab ja seab piire diskursusele, mis käsitleb sloveenide ja sloveeni kogukonna seisundit Kärntenis. Iga Austria lepingu punkti seitse aspekt, mis puudutab sloveeni kogukonna õigusi Kärntenis ja Austria riigi kohustusi, taandub tema kõnes kakskeelsete siltide teemale.

Need mõned sõnad sloveeni keeles osutavad ka Kärnteni probleeme puudutavatele kaksipidistele tunnetele, mis on iseloomulikud sloveeni etnilise kogukonna käsitlusele ja retseptsioonile; need on seotud mitte ainult konkreetse ja kompleksse lahenduse vaheliste suhetega, vaid ka 'enamuse' ja 'vähemuse' vaadetega. 
Kohalike ja regionaalsete, rahvuslike ja meediadiskursuste vastastikune mõju ning ka enamuse vaated ilmnesid selgelt näiteks telesaates, kus käsitleti kakskeelseid silte ${ }^{8}$ ja milles ainult üks kuuest külalisest, kes rääkis sloveeni etnilisest vähemusest, oli ise sloveen. Valentin Inzko oli ainuke, kes väljendas arvamust, mis nõudis põhjalikumat sloveeni etnilise vähemuse tunnustamist, mis hõlmaks ka kakskeelseid silte. Lisaks ülejäänud viiele külalisele pöördus ta ka Austria avalikkuse poole, kuna Austria riigi esindajad saavad kiirendada kohalike võimude nõudmiste täitmist. Sellises olukorras, nagu dr Inzko end leidis, on peaaegu võimatu vältida patuoinaks saamist, sest igaüks, kes väljendab valitsevast erinevat seisukohta, mõistetakse juba eos hukka või teda peetakse tülinorijaks.

Järgmine probleem, mis kerkib esile aruteludes dr Josef Feldneriga ning haritlaste ja ajaloolastega erinevatest Kärnteni riigiasutustest, puudutab sageli väljendatud arvamust selle kohta, kui suuremeelne on või peaks olema saksa enamus sloveeni vähemuse suhtes. Kõige täpsemalt defineeritud arvamus on Feldneril ja ta väljendab seda Konsensusgrupi raames: "Kuna meil on 97protsendiline enamus, võime me endale lubada olla suuremeelsed ilma seadust täht-tähelt jälgimata." ${ }^{\prime \prime}$ helt poolt on Feldneri suuremeelsus peaaegu 100protsendilise enamuse arvamuse väljendus; teisalt põhineb see aga lootusel, et Sloveenia näitab samuti üles suuremeelsust ja tunnustab oma põlissakslastest elanike põhiõigusi. ${ }^{10}$

Josef Feldner ütles ühes intervjuus ${ }^{11}$ ja kordas seda ka televisioonis esinedes, et Kärnteni Heimatdienstil on rohkem liikmeid kui ametlike andmete järgi sloveene, seega karta pole midagi. ${ }^{12}$ See "suuremeelne" arvamus kinnitab piirkondlikke ja etnilisi struktureeringuid ja ütleb nii mõndagi võimujaotuse kohta, selle kohta, kes valitseb piirkonda ja kes otsustab, mida vähemuse esindaja tohib või ei tohi teha.

Valentin Inzko kõne, kakskeelsed kohanimed mõnede Kärnteni asulate siltidel ja Austria presidendi sõnad avasid niši Kärntenisse ja Austriasse kuulumise olemasolevates kuvandites ja pakkusid erinevaid võimalusi selle rituaali poliitiliseks tähistamiseks.

Neid võimalusi ning vajadust erinevate mälestusürituste järele mainisid 2010. aastal ka osavõtjad ise, kui nad kritiseerisid ürituse kehva organiseerimist, ebapiisavat korraldust ja pikki ooteaegu. Andrea Bergmann käsitles neid organisatsioonilisi küsimusi artiklis, mis avaldati Kärnteni kõige esinduslikumas ajalehes Kleine Zeitung, ja milles autor küsib ürituse peaorganisaatorilt Horst Moserilt, kas on üldse mõtet paraadi korraldada, kui seda tuleb vaatama ainult paar tuhat inimest. ${ }^{13}$ Palju otsesem kriitika paraadist osavõtjatelt ilmus aga anonüümses vormis Bergmanni artikli kommentaaride osas. 


\section{Opositsiooni kuvandid: meeleavaldustest mälestusüritusteni}

Ideed ja kombed, mida esitleti Kärnteni rahvahääletuse mälestusüritusel, ja eriti rituaalid, mida viisid läbi üliõpilaskorporatsiooni Ulrichsberg Burschenschaft liikmed, on vastuolulised väiksemate, alternatiivsete gruppide seisukohalt, kes on viimastel aastatel koondunud peamiselt kahe mõiste ümber - selgitamine (Aufklaeren) ja mäletamine (Erinnern). Selles kontekstis on kinnistunud erinevad tavad.

Üks neist on otseselt seotud rahvahäl̈letuse mälestamisega ja on koondunud Klagenfurti: aastal 2010, paraadi eelõhtul, korraldas antifašistlik grupeering ANTIFA Klagenfurtis demonstratsiooni. Nad protesteerisid rahvahääletuse mälestusürituse saksameelse natsionalistliku iseloomu vastu, mis ignoreerib teist, erinevat, ja välistab mitte ainult sloveenid, vaid ka immigrandid.

Teised praktikad on seotud peamiselt natsismi ja fašistliku vägivalla ohvrite mälestamisega nii Loibli koonduslaagris kui ka Klagenfurtis. Kohalikud ja rahvusvalitsused ei kiitnud neid ettevõtmisi heaks ega ka organiseerinud neid. Toetajateks olid üksikisikud, nagu näiteks dr Peter Gstettner, Franc Wakounig, Hans Haider (Villach), ja ühingud, kuhu nad kuulusid. Mälestustseremooniatest, mida korraldati nii Austria poolel kui ka Sloveenias nende auks, kes hukkusid Loibli koonduslaagris, mis oli osa Mauthausenist, võtsid osa ka laagris ellujäänud.

Teistest erinev praktika, mille stsenaarium ja ülesehitus põhineb rituaalil, on nn Schweigemarsch ehk Gedenk-Gehen ${ }^{14}$ - mälestuskõnd. See on toimunud igal aastal, alates aastast 2008, aprillikuu viimasel nädalal. Sellega mälestatakse fašismi- ja natsismivastase võitluse ohvreid aastatest 1941-1945. Erikohtud, mille eesistujaks oli tavaliselt 'verine' kohtunik dr Roland Freisler (Baum 2011), mõistsid ohvreid surma poomise või pea maharaiumise läbi. Kohtuotsuseid viidi täide veel paar kuud enne sõja lõppu. Siinkohal tuleks märkida süüdimõistetud naiste ebaproportsionaalselt suurt arvu ja nende hukkamise iseloomu. Ainuüksi viimasel istungil tehtud kohtuotsuse põhjal 1945. aasta jaanuaris poodi üles kuus meest ja hukati pea maharaiumise teel viis naist.

Rituaalne praktika, mida algselt soovitas Franc Wakounig ja mille elluviimisega tegi algust Kärnteni Mälestusühing, määratleb igal aastal uue sisu (nt 2013. aastal avati kohtuhoone ees mälestustahvel, millel on natsismivastases liikumises langenud inimeste nimed), milles eristuvad põhitunnustena näiteks marss, kõned, preestri osalemine, jne. See rituaal on tähtis ja huvitav selle poolest, et see väljendab teatud suhtumist sloveeni etnilisse vähemusse, kuna peaaegu kõik natsliku agressiooni ja režiimi ohvrid olid sloveeni kogukonna liikmed. 
Aastal 2008, Jörg Haideri ametisoleku ajal, mil see komme alguse sai, oli see vastuoluline. Organisaatorid pidid hankima kohalikelt võimudelt spetsiaalse loa, mida ei antud enne, kui nad ähvardasid kaasata meedia. ${ }^{15}$ Aastal 2011, mil ma seda praktikat uurisin, mainiti seda nii Kärnteni ajalehes Kleine Zeitung kui ka Austria rahvustelevisioonis ORF. Nende hulgas, kes esinesid kõnega endise gestaapo peakorteri asukohas, kust vangid viidi kohtumajja ja sealt edasi hukkamisele, oli dr Peter Kaiser, tolleaegne (teine) Kärnteni viitsekuberner, kes oli ka Austria Sotsiaaldemokraatliku Partei esindaja Kärnteni Maapäeval.

See rituaalne tava muutus ametlikuks alles 2013. aastal, mis langes kokku märtsivalimiste ja Kärnteni kohalikus omavalitsuses toimunud muudatustega. See oli aeg, mil parempoolsed parteid, eriti Vabaduse Partei, kaotasid oma tähtsuse, eelkõige Hypopanga afääri (vt Economist 2010) ja teiste skandaalide tõttu. Sümboolsel tasandil muutis see ka suhtumist kakskeelsusesse. Kui dr Peter Kaiser valiti riigikuberneriks, kasutas ta otsustavalt sloveeni keelt kõikvõimalikes situatsioonides; samuti rääkis mõlemas keeles sloveeni etnilise kogukonna esindaja.

Dr Bernd Lutschounig, Klagenfurti kohtunik, ja peasüüdistaja dr Mirko Borotschnik võtsid sõna 2013. aasta mälestusüritusel, ning Franc Wakounig rääkis varasemast agressioonist sloveeni kogukonna ja kõigi natsismiohvrite vastu. See, et mälestustahvlit toetas rahaliselt ka riigisekretär Wolfgang Waldner, räägib teatud mõttes ametlikust tunnustamisest ja minevikuga lepituse otsimisest.

Selliseid rituaalseid praktikaid võib mõista kui uusi katseid, sarnaselt nendele, mida korraldasid Concordia et Pax rühmitis Görzi piirkonnas (vrd Fikfak 2009), rühmitis Erinnern Villachis ${ }^{16}$, või Mauthauseni grupi tegevuskomitee. Viimane koos dr Peter Gstettneriga organiseeris ka analoogse programmi mälestamaks neid, kes saadeti koonduslaagritesse Austria poolele Loiblisse. See üritus kujutab endast rituaali, mille sisu on seotud surnute ja süüdimõistetute mälestamisega. Mälestatakse ka neid, kes ütlesid ei natsismile ja vägivallale nende suhtes, kes olid teistest erinevad. See puudutab nii pealtvaatajaid kui ka osavõtjaid, kelle hulgas on nii koonduslaagrites ellujäänuid kui ka ohvrite lapsi ja teisi sugulasi. Nendega on ühinenud ka inimesed, kes toetavad erinevusi ja minevikku süüvimist.

Meediadiskursustes peetakse sellist rituaalset käitumist ikka veel marginaalseks. Austria riigitelevisioon paigutab sellekohase info vähemusi käsitlevate teadete hulka; seega ei käsitleta neid samal tasandil kui sündmusi, mis puudutavad kogu Kärnteni liidumaad. Samas vaimus avaldas ka Kärnteni ajaleht Kleine Zeitung 25. aprillil teadaande üritusest, mis pidi toimuma 29. aprillil, kuid ei kommenteerinud seda sündmust 30. aprillil, sellele järgneval 
päeval. Selle sündmuse ainus märkimisväärne vastukaja Sloveenias oli põhjalik ülevaade Boris Jaušovecilt (2013) päevalehes Večer.

Võib öelda, et selle rituaalse sündmuse lavastamine, vastuvõtt ja tunnetamine on aja jooksul muutunud. Avalikkuse reageeringutest on silmanähtav, et mälestuskõnd on muutumas üheks kõige tüüpilisemaks rituaalseks ettevõtmiseks Klagenfurtis. Kuna see kaasab mitmeid osapooli, kuid peamiselt tänu oma asetusele laiemas kontekstis, mis käsitleb natslik-fašistlikku agressiooni ja Austria rolli selles, ületab mälestuskõnd sloveeni etnilise kogukonna piirid. Rituaalide analüüs näitab, et muutus on lahutamatu osa diskursustest (mida mõjutavad valitsevad struktuurid kohaliku valitsuse, konstitutsioonikohtu ja riigi tasandil), mis kasutavad järjest enam enesessesüüvimist, mõjutamaks tunnetuses toimuvaid muutusi.

Narratiivid rituaalsetest praktikatest käsitlevad ritualiseerimist, pidevat arutelu, järjestamist ja rutiini kriisiolukorras, samuti uute ruumide avanemist otsusteks, järjekordseteks muutusteks ja pööreteks.

Näiteks aastal 2009 otsustasid sõjaväelased ja kaitseminister Norbert Darabos distantseerida end mälestuskogenemisest, mis toimus Ulrichsbergi mäel. ${ }^{17}$ Teise näite vaadete muutumisest võib leida Josef Feldneri juhitud Kärnteni Heimatdienstist, mis muutis oma saksameelsust kaitsvat seisukohta ning osales kahe keelerühma vahelise konsensuse loomises. Seda muutust rõhutab ka nelja asula osalemine Klagenfurti rongkäigus kakskeelsete loosungitega. Nende otsus osutab selgelt muutunud arusaamadele etnilisusest kui erinevast minakäsitlusest ja sloveeni kogukonna enesepresentatsioonist.

\section{Kokkulepped ja (uus)tõlgendused}

Mõlema rituaalse praktika kohta võib öelda, et nad on liikumises ja kriisis. Oktoobris Klagenfurti tänavatel toimuva mälestusparaadi puhul on järjest vähem selge, keda see üritus peaks kõnetama. Keda või mida kehastavad need inimesed, kes marsivad selles rongkäigus? Keda nad kõnetavad, kes on sellesse kaasatud ja kes ikka veel välistatud? Pealtvaatajate arvu vähenemine näitab, et huvi selle ürituse vastu kahaneb ja et see on muutunud vähem tähtsaks. See ei ole enam sama oluline maa kuvandi jaoks nagu rohkem kui kakskümmend aastat tagasi, kui suur riik - Jugoslaavia - piidles kõike üle Karavangide.

Teine rituaalne tava on samuti muutumas - mitte ainult selle kuvand ja järkjärguline ritualiseerimine, vaid ka selle suhteliselt aeglane kehtestamine kohaliku ja rahvusliku tasandi diskursustes. Ohvrite mälestamine, olgu siis Klagenfurtis või Loibli koonduslaagri asukohas, tugevdab vajadust mõtiskleda Austria rolli üle teiste ja erinevate natslikus tagakiusamises. 
Me näeme rituaalsete praktikate tähenduste muutumist, nende (uus)tõlgendusi ja pidevaid neid puudutavaid kokkuleppeid. Siinkohal võiks näiteks mainida Kärnteni Riikliku Muuseumi ajaloolaste soovi teha koostöös oma Sloveenia kolleegidega rahvahääletusest näitus, samuti Austria presidendi Heinz Fischeri kõnet. Veelgi tähtsam oli aga Valentin Inzko kõne, milles ta nihutas tähelepanu keskpunkti süntagmalt 'jagamatu ja ühtne Kärnten' süntagmale 'Kärnten koos teisega, koos naabriga'. Kõik need on hiljutised tegevused ja rituaalsed ettevõtmised, mis loovad ruumi erinevatele diskursustele ja võimaldavad erinevat mälestamispoliitikat.

Selles kontekstis peeti Völkermarktis mälestusüritus, mis oli pühendatud kõigile langenud kaitsjatele - "neile, kes võitlesid Sloveenia põhjapiiri eest, ja kärntenlastele, kes võitlesid Kärnteni ühtsuse eest”. ${ }^{18}$

Muutused riigivõimuesindajate ridades olid eriti olulised rituaali tunnetamise ja lavastamise seisukohalt. Rõhutama hakati ametliku diskursuse uusi ja erinevaid elemente. Esinedes oktoobris 2013 rahvahääletuse aastapäeval Annabilchi kalmistul oleva mälestusmärgi juures kandis riigikuberner dr Peter Kaiser kohaliku traditsioonilise kostüümi asemel tavalist igapäevast ülikonda. Oma kõnes ütles ta ka mõned sõnad sloveeni keeles, ja ametlikul plakatil oli järgmine moto, mõlemas keeles ja ühesuuruste tähtedega:

Zukunft gestalten; Vergangenheit verstehen.

Prihodnost oblikovati; preteklost razumeti.

[Kujundada tulevikku; mõista minevikku.]

Tõlkinud Tiina Mällo

\section{Kommentaarid}

1 Vthttp://ec.europa.eu/archives/publications/booklets/eu_documentation/04/txt_en.pdf_13. juuni 2015.

${ }^{2}$ Sloveenia pressiagentuur teatas, et Kärnteni Sloveenide Rahvusnõukogu (NSKS) ei kutsutud osalema tseremoonia organiseerimises; oma pöördumises Kärnteni Maapäeva poole väljendas NSKSi president Valentin Inzko lootust, et Kärnten muutub edumeelsemaks ja hakkab oma sloveeni vähemust rohkem toetama (http://www.sta. si/en/vest.php?s=a\&id=1556191 - 13. juuni 2015).

${ }^{3}$ Konsensusrühma liikmed püüavad algatada dialoogi Kärnteni erinevate rahvusrühmade - eriti sloveeni-ja saksakeelsete kogukondade - vahel. Rühm on oma jõupingutuste eest saanud mitmeid Austria ja Euroopa auhindu (http://www.kleinezeitung.at/ kaernten/3104293/vierte-auszeichnung-fuer-konsensgruppe.story - 13. juuni 2015).

4 Originaaltekst: Kärnten begeht das stolze Jubiläum "90 Jahre Volksabstimmung" unter dem Motto "Gestern - Heute - Morgen”. Auf dem Fundament der gemeinsamen 
Geschichte gilt es, gemeinsam die Zukunft zu gestalten. Vor 90 Jahren hat die Kärntner Bevölkerung eine klare Entscheidung für den ungeteilten Verbleib ihrer Heimat bei Österreich getroffen. Das Bekenntnis zur Einheit Kärntens war nicht nur ein Sieg der Demokratie, sondern auch eine klare Absage an den damals in Europa vorherrschenden Nationalismus, weil deutsch- und slowenischsprachige ebenso wie windische Kärntner gemeinsam für das neue Österreich und gegen den großserbischen SHS-Staat stimmten.

5 Originaaltekst:

\section{Oktober}

13.00 Uhr Festsitzung des Kärntner Landtages im Großen Wappensaal des Landhauses 15.00 Uhr Festakt zum Jubiläum im Großen Wappensaal des Landhauses mit Reden des Herrn Bundespräsidenten, des Herrn Bundeskanzlers und des Herrn Landeshauptmannes, musikalische Umrahmung durch zwei Jugendchöre (deutsch und slow.), Einbindung der slow. Volksgruppe (ORF-Direktübertragung)

\section{Oktober}

9.30 Uhr Abstimmungsgedenkfeier beim Ehrenmal auf dem Soldatenfriedhof in Annabichl

11.00 Uhr 10.-Oktober-Feier des Landes Kärnten im Landhaushof-Stätte der Kärntner Einheit

14.00 Uhr Kranzniederlegungen an den Gräbern von Landesverweser Dr. Arthur Lemisch (Dreifaltigkeit bei St. Veit/Glan), Dr. Martin Wutte (Obermühlbach bei St. Veit/ Glan) und Obstlt. Ludwig Hülgerth (Schloss Rottenstein).

6 Kõne on olemas nii sloveeni kui ka saksa keeles aadressil http://issuu.com/nedelja/docs/ inzko - 13. juuni 2015. Ülevaadet kõnest vt Festlicher Auftakt im Jubiläumsreigen. Klagenfurt, ÖRF, 8. oktoober, 2010, aadressil http://ktnv1.orf.at/stories/474845 13. juuni 2015.

7 Dr. Fisheri ametisseastumiskõnet kajastas näiteks ajaleht Kleine Zeitung 8. juulil 2010. aastal (http://www.bundespraesident.at/newsdetail/artikel/rede-vonbundespraesident-heinz-fischer-in-klagenfurt-anlaesslich-90-jahre-kaerntnervolksabstimm/ - 13. juuni 2015).

8 Telesaates "Im Zentrum" (ORF2) 10. aprillil 2011 diskuteeris saatejuht Ingrid Thurner topograafiliste märkide üle Austria föderaalkantselei riigisekretäri dr Josef Ostermayeri, Kärnteni kuberneri Gerhard Dörfleri, Kärnteni Sloveenide Rahvusnõukogu esimehe Valentin Inzko, Kärnteni Heimatdiensti juhi Josef Feldneri ja ajalehe Kleine Zeitung ajakirjaniku Antonia Gössingeriga (http://www.be24.at/blog/entry/657253 13. juuni 2015). Huvitav on see, kuidas reporterid mainisid Ostermayeri doktoritiitlit, kuid jätsid tähelepanuta Inzko ja Feldneri tiitlid.

9 Originaaltekst: Mit unserer 97\%igen Mehrheit können wir es uns leisten, großzügig zu sein und nicht kleinlich auf dem Buchstaben des Gesetzes zu kleben. Statement Informations- und Diskussionsveranstaltung. St. Michael ob Bleiburg/Šmihel nad Pliberkom, 22. Juli 2010 von Josef Feldner, Obmann Kärntner Heimatdienst (http:// www.zeitdokument.at/ztdok/b_txzz02.html - 13. juuni 2015).

${ }^{10}$ Originaaltekst: Bei Großzügigkeit gegenüber unserer kleinen slowenischen Volksgruppe dürfen wir umso berechtigter auch vom Nachbarstaat Slowenien Großzügigkeit erwarten gegenüber der heute nur mehr wenige Tausend Personen umfassenden autochthonen deutschen Volksgruppe und die endliche Zuerkennung von Basisrechten verlangen (http://www.zeitdokument.at/ztdok/b_txzz02.html - 13. juuni 2015). 
${ }^{11}$ Inglis- ja saksakeelsed jutuajamised Kärnteni poliitika silmapaistvate esindajatega (dr Rudi Vouk, dr Josef Feldner, dr Klaus Ottomeyer) pärinevad autori ja dr Thomas Wolfe'i (Minnesota Ülikool, USA) kogutud materjalidest.

${ }^{12}$ Hinnangud Heimatdiensti liikmelisuse kohta on erinevad; isegi Feldner mainib arve 15000 ja 20000 vahel. Mõningaid järeldusi võib teha hääletussedelite arvu (5000) põhjal, mida kasutati, kui Josef Feldner uuesti presidendiks valiti; nagu märgib ka foto kõrval olev tekst ajalehes Kleine Zeitung 14. septembril 2012: 100 liiget ja 10000 toetajat (http://tinyurl.com/ny7xheo - 13. juuni 2015).

${ }^{13}$ Andrea Bergmann esitas küsimuse: "Ob es in Anbetracht der wenigen tausend Zuschauer entlang der Umzugsstrecke überhaupt noch einen Festumzug geben soll?" [Kas mõne tuhande pealtvaataja pärast teeservas üleüldse veel pidulikku rongkäiku mängima peab?] Horst Moser vastas: "Das entscheidet die Politik." [Seda otsustab poliitika] (http://www.kleinezeitung.at/kaernten/volksabstimmung/2513597/zornkritik-nach-dem-festumzug.story\#forummain - 13. juuni 2015).

${ }^{14}$ Kasutusel on erinevaid nimesid. Kõige hilisem - Gedenk-Gehen (mälestuskõnd) pärineb aastast 2013 (Franc Wakounigilt).

${ }^{15}$ Informatsioon pärineb Franc Wakounigilt.

${ }^{16}$ Hans Haider räägib sellest rühmitisest üksikasjalikumalt aadressil http://www. net4you.com/haiderftp/ueber/index.html - 13. juuni 2015.

${ }^{17} \mathrm{Vt}$ http://www.presseurop.eu/en/content/news-brief/84821-ach-no-more-ss-tributes 13. juuni 2015.

${ }^{18}$ Marjan Sturm kirjutas sellest ühes oma arvamusveerus pealkirja all Marjanizmi (Marjanismid), mis avaldati 11. oktoobril 2013. aastal ja oli olemas aadressil http:// www.slo.at/zso/sturm_sl_more.php?id=1746_0_6_0_m (lehekülg ei ole enam kättesaadav, viimane külastus 5. jaanuaril 2015):

\section{Dialoogi- ja koostööpoliitika tasub end ära}

Hiljuti organiseeriti kaks olulist üritust: Feldner ja mina algatasime kõigi langenute mälestusürituse Völkermarktis "nende mälestuseks, kes võitlesid Sloveenia põhjapiiri eest, ja kärntenlaste mälestuseks, kes võitlesid Kärnteni ühtsuse eest”. Mälestusürituse motoks oli: "Nad surid, uskudes oma kodumaasse". See oli äärmiselt inimlik ja aupaklik sõnum, mille sarnast polnud Kärntenis kunagi varem kuuldud. Feldner rõhutas, et arvestada tuleb ka kõikide natsionaalsotsialismi ohvritega kogu maal. Me kutsusime osalema ka Kindral Maisteri Ühingu esindajad, kes polnud isegi teadlikud sellest, et Völkermarktis selline kalmistu on, ja kes Klagenfurtis leviva informatsiooni tôttu ei osalenud mälestusüritusel. Nii ei tohiks oma langenute inimlik ja aupaklik kohtlemine välja näha.

Rahvahääletuse mälestamine toimus sel aastal natuke erinevalt eelmistest. Sloveenid olid oodatud osa võtma, meie keelt võis kuulda, ning mälestusüritus oli taktitundeline ja austustavaldav. Noored ja riigisekretär lubati poodiumi keskele. Feldner ja mina vastasime väitlusjuhi küsimustele selle kohta, miks me alustasime riigis dialoogipoliitikat. Hiljem peatasid mind tänaval inimesed, kes onnitlesid mind minu poliitilise tegevuse puhul. Paljugi on muutunud ja ma tunnen natuke uhkust oma osa üle selles. 


\section{Kirjandus}

Austin, John L. 1962. How to Do Things with Words: The William James Lectures Delivered at Harvard University in 1955. Oxford: Clarendon Press (http://www.dwrl. utexas.edu/ davis/crs/rhe321/Austin-How-To-Do-Things.pdf - 1. juuli 2015).

Baum, Wilhelm 2011. Die Freisler-Prozesse in Kärnten: Zeugnisse des Widerstandes gegen das NS-Regime in Österreich. Klagenfurt: Kitab.

Burz, Ulfried \& Pohl, Heinz-Dieter (toim) 2005. Politische Festtagskultur in Kärnten: Einheit ohne Einigkeit? Kärnten und die nationale Frage 3. Klagenfurt: J. Heyn.

Cernigoi, Claudia 2005. Operazione "Foibe": Tra storia e mito. Udine: Resistenza storica Kappa vu.

Economist $2010=$ The Austrian bank at the centre of a growing web of scandal. The Economist, 9. september (http://www.economist.com/node/16996984 - 1. juuli 2015).

Fikfak, Jurij 2009. Cultural and Social Representations on the Border: From Disagreement to Coexistence. Human Affairs 19 (4), lk 350-362 (http://dx.doi.org/10.2478/ v10023-009-0049-1).

Gerndt, Helge 1979. Gedanken zum Festwesen der Gegenwart. Traditiones 5-6, lk 153161.

Hayek, Friedrich August 1960. The Constitution of Liberty. Chicago, IL: University of Chicago Press.

Inzko, Valentin 2010. Das gemeinsame Kärnten: Skupna Koroška. Rede anlässlich des 90. Jahrestages der kärntner Volksabstimmung im grossen Wappensaal des Landhauses zu Klagenfurt / Govor ob 90. Obletnici plebiscita v Veliki dvorani grbov v deželnem dvorcu v Celovcu. Klagenfurt/Celovec, 8. oktoober (http://www.skupnost.at/wp-content/ uploads/govor_dr_inzko_sc.pdf - 1. juuli 2015).

Jaušovec, Boris 2013. Za nacizem so bile žrtve preveč človeške. Večer, 29. aprill (http:// ris.vecer.com/arhivi/arhiv.aspx - 1. juuli 2015).

Lukes, Steven 1975. Political Ritual and Social Integration. Sociology 9 (2), lk 289-308 (http://dx.doi.org/10.1177/003803857500900205).

Moritsch, Andreas 2002. Sozialwirtschaftliche Voraussetzungen der Entwicklung zum 10. Oktober 1920 in Kärnten. Hellwig, Valentin \& Haiden, Susanne \& Maier, Barbara (toim). Die Kärntner Volksabstimmung 1920 und die Geschichtsforschung. Klagenfurt: Heyn, lk 221-224 (saksa keeles); lk 348-349 (sloveeni keeles).

North, Douglass C. 1991. Institutions. Journal of Economic Perspectives 5 (1), lk 97-112 (http://dx.doi.org/10.1257/jep.5.1.97).

Oevermann, Ulrich 2001. Die Philosophie von Charles Sanders Peirce als Philosophie der Krise. Wagner, Hans-Josef (toim). Objektive Hermeneutik und Bildung des Subjekts. Göttingen: Velbrück Wissenschaft, lk 209-246.

Petrei, Bertl 1986. Der Kokolore: Menschen und Geschichten einer Kindheit. Klagenfurt: Heyn Verlag. 
Petrei, Bertl 1995. DAS WINDISCHE - ein letzter Versuch. Aus: Die Kärntner Landsmannschaft (http://www.windische.at/AKADEMIE_FI/GESCHICHTE/AK_GE_ Petrei.htm - 1. juuli 2015).

Pirjevec, Jože 2009. Foibe Una storia d'Italia. Torino: Giulio Einaudi Editore.

Pupo, Raoul \& Spazzali, Roberto 2003. Foibe. Milano: Bruno Mondadori.

Slovene-Italian Relations 2000 = Slovene-Italian Relations $1880-1956$ by the SloveneItalian Historical and Cultural Commission. Koper-Capodistria, 25. juuli (http://www. theslovenian.com/articles/sihcc.htm - 1. juuli 2015).

Zinkner, Martin Alois 2009. Analyse des Kärntner Ortstafelkonfliktes: Gesetze, Akteure und Möglichkeiten. Diplomarbeit. Wien: Universität Wien (textfeld.ac.at/pdf/1667.pdf1. juuli 2015).

Valentin, Hellwig 2006. Die Entwicklung der nationalen Frage in Kärnten 19181945/ Razvoj nacionalnega vprašanja na Koroškem 1918-1945. Valentin, Hellwig \& Karpf, Peter \& Puschnig, Udo (toim). Der Staatsvertrag von Wien 1955-2005: Die Kärntner Perspektiven. Kärnten Dokumentation 22. Klagenfurt: Amt der Kärntner Landesregierung, lk 31-88 (http://www.volksgruppenbuero.at/images/uploads/band22_ final_sc.pdf - 1. juuli 2015).

Wydra, Harald 2009. The Liminal Origins of Democracy. International Political Anthropology 2 (1), lk 91-109 (http://www.international.politicalanthropology.org/ images/articles/2009_1/ipa_journal_1_2009_wydra.pdf - 1. juuli 2015).

\section{Summary}

\section{Political Rituals and Discourses: The Case of Carinthia}

Jurij Fikfak

Keywords: alternative practices, memorial walk, Nazism, plebiscite, ritual practices, use of discourse

This article discusses selected ritual practices in Klagenfurt (Sln. Celovec), the capital of the southernmost Austrian state of Carinthia (Germ. Kärnten). The first ritual is connected with October 10, when the 1920 plebiscite is commemorated on the streets of Klagenfurt. In this plebiscite, the majority of people voted for remaining a part of Austria, the successor state to Austria-Hungary. The second ritual is a more recent one, known as the Memorial Walk (Germ. Gedenkgehen, Sln. Spominska hoja). Various cultural practices are analysed, as well as the use of symbols and space, media, state, and national discourses. 